\title{
Character Association and Path Coefficient Analysis for Seed Yield and Latex Yield in Opium Poppy (Papaver somniferum L.)
}

\author{
Gurudatt Solanki ${ }^{1}$, N.S. Dodiya ${ }^{1}$, Ram Kunwar ${ }^{1}$, Prashant Bisen ${ }^{1}$, \\ Ramesh Kumar ${ }^{1}$, Jagjeet Singh ${ }^{2}$ and Sandhya ${ }^{2 *}$ \\ ${ }^{1}$ Department of Plant Breeding and Genetics, Rajasthan College of Agriculture, Maharana Pratap \\ University of Agriculture and Technology, Udaipur - 313001, Rajasthan, India \\ ${ }^{2}$ Institute of Agricultural Sciences, Banaras Hindu University, Varanasi-221005, India \\ *Corresponding author
}

\section{A B S T R A C T}

\begin{tabular}{|c|c|}
\hline Keywords & An investigation was carried out using 20 opium genotypes, to study character association \\
\hline $\begin{array}{l}\text { Papaver } \\
\text { somniferum, } \\
\text { Genotypic } \\
\text { correlation, } \\
\text { Phenotypic } \\
\text { correlation, } \\
\text { Path analysis. }\end{array}$ & $\begin{array}{l}\text { yield independently. Association study indicated that seed yield per plant had significant } \\
\text { positive correlation with diameter of main capsule }(0.60) \text { and latex yield per plant }(0.60) \text {. } \\
\text { Whereas latex yield per plant had significant positive correlation with days to } 50 \text { per cent } \\
\text { flowering }(0.53) \text { and seed yield per plant }(0.60) \text {, indicating that seed yield and latex yield } \\
\text { per plant can be improved by improving these correlated characters. Path coefficient } \\
\text { analysis revealed that number of effective capsules per plant }(73.04,77.88) \text { contributed } \\
\text { most directly towards seed yield per plant and latex yield per plant, respectively. Whereas, }\end{array}$ \\
\hline Article Info & $(29.35,32.39)$, morphine content $(21.33,22.34)$ contributed both directly and indirectly to \\
\hline $\begin{array}{l}\text { Accepted: } \\
\text { 14 June } 2017 \\
\text { Available Online: } \\
10 \text { August } 2017\end{array}$ & $\begin{array}{l}\text { seed yield per plant and latex yield per plant, respectively. Therefore, this is suggested that } \\
\text { the traits viz., no. of effective capsules per plant, stem diameter, peduncle length, plant } \\
\text { height and morphine content may be considered as important traits during the selection for } \\
\text { improvement of seed yield as well as latex yield per plant in opium. }\end{array}$ \\
\hline
\end{tabular}

\section{Introduction}

Papaver somniferum L. commonly known as opium poppy is an annual plant $(2 n=22)$ native to Turkey and adjacent areas. Opium poppy is considered to be a predominantly self-pollinating species with various rates of out-crossing depending upon variety and environmental factors where the degree of out crossing is reported from 70-72 per cent. The transfer of pollen from one flower to another might also be performed by wind (Patra et al., 1992). Opium has medicinal or ornamental use, as well as a source for seeds, seed oil.
Opium known as a source of several alkaloids used for antispasmodic, analgesic, antitussive, hypnotic, sudorific and sedative, purpose in modern medicine. Morphine is the major alkaloid present in opium ranges from 7-17 per cent mainly used to relieve from almost all type of severe pains (Yadav et al., 2008).

Opium seeds are devoid of narcotic properties and are rich in fatty oils and proteins. Opium seeds contain up to 50 percent edible oil and cultivar having high levels of oleic and 
linoleic acids (Singh et al., 1990). The oil is widely used for culinary purposes and in salad dressing. It is non yellowing drying oil forming a hard and lustrous film and therefore also used in production of artist's paints. The seeds are a good source of energy. They are also the source of dying oil, used for manufacturing of paints, varnishes and soaps. Oil cake is a good fodder for cattle (Harvey, 1988; Duke, 1989).

In India, it is cultivated in the states of Madhya Pradesh, Rajasthan and Uttar Pradesh under the control of Narcotics Department by licensed growers and is a valuable source of foreign exchange. In Rajasthan opium poppy is mainly grown in Chittorgarh, Paratapgarh, Udaipur, Jhalawar, Kota, Bundi, Anta and Bara district over an area of about 6000 ha with a production of 337 tones latex with average productivity of $60 \mathrm{~kg}$ latex per ha (Anonymous, 2011). India produces about half the opium utilized by the world's pharmaceutical industries to produce codeine, morphine, narcotine, thebaine, papaverine and other medical products.

There is a large opportunity for improvement of yield to suit the needs of Rajasthan opium grower. Correlation and path analysis will establish the extent of association between yield and its components and will also bring out the relative importance of their direct and indirect effects (Namrata et al., 2016). Correlation studies provide an opportunity to study the magnitude and direction of association among different traits with seed yield and latex yield component and their direct and indirect effect on seed yield as well as on latex yield. Path coefficient is the standardized partial regression coefficients and provides the true contribution of the characters towards the yield (Thakur et al., 2015). To exploit optimum combination of yield contributing characters in a single genotype, it is essential to entail the implication of the inter relationships of various characters along with path coefficients.

\section{Materials and Methods}

\section{Experimental material and design used}

The present investigation confined twenty diverse opium genotypes including three checks viz., IC 42, CHETAK APHIM and MOP 540, received from AICRP on Medicinal and Aromatic plant (Plant Breeding Unit), Rajasthan College of Agriculture, MPUAT, Udaipur (Table 1). These genotypes were evaluated in randomized block design replicated thrice during rabi 2013-14. Each entry was planted in 4 rows of $3.0 \mathrm{~m}$ length keeping row to row and plant to plant distance of $30 \mathrm{~cm}$ and $10 \mathrm{~cm}$, respectively.

\section{Traits observed}

The observations were recorded on fourteen characters viz., days to 50 per cent flowering (DF), peduncle length (PL), plant height $(\mathrm{PH})$, number of leaves per plant (LPP), number of effective capsule per plant (ECP), diameter of main capsule (CD), stem diameter (SD), seed yield per plant (SYP), husk yield per plant (HYP), latex yield per plant (LYP), harvest index for seed yield (HISY), harvest index for latex yield (HILY), seed oil content (SOC), morphine content (MC). The representative bulk sample from each entry in each replication was used for analysis of morphine content and seed oil content.

\section{Statistical analysis}

Correlation Analysis were done using the procedure suggested by Fisher (1954) and AlJibouri et al., (1958), whereas method suggested by Dewey and Lu (1959) were used for path coefficient analysis. 


\section{Biochemical analysis}

Morphine content of latex was estimated following the procedure suggested by Pride and Stern (1954) and for seed oil content Soxhlet method (A.O.A.C. 1965) was used.

\section{Results and Discussion}

\section{Correlation analysis}

Correlation studies indicate a true picture of association between any pair of character. In some cases, where desired trait is unpredictable till the end, association studies is very important to find out the impact of other predictable traits on the desired traits. Correlation of seed yield per plant with its components at genotypic $\left(\mathrm{r}_{\mathrm{g}}\right)$ and phenotypic $\left(\mathrm{r}_{\mathrm{p}}\right)$ levels are presented in table 2. The perusal of data given in table 1 revealed that, the genotypic correlation coefficients were relatively higher than their corresponding phenotypic correlations (Tiwari et al., 2000), which may be due to masking effect of environment in modifying the total expression of genotype (Singh et al., 2004; Kumar et al., 2014). The degree of association was quantified on the basis of phenotypic and genotypic correlation coefficient.

Seed yield per plant exhibited significant positive genotypic correlation with diameter of main capsule $\left(0.60^{* *}\right)$ and latex yield per plant $\left(0.60^{* *}\right)$, whereas it exhibited a strong positive significant phenotypic correlation with husk yield per plant $\left(0.77^{* *}\right)$. The husk yield per plant had positive significant genotypic correlation with diameter of main capsule $\left(0.59^{* *}\right)$ and stem diameter $\left(0.57^{* *}\right)$. Mirjana et al., (2012); Jain et al., (2006), and Jain et al., (2005), found strong positive correlation of number of traits viz., diameter of main capsule and husk yield per plant with seed yield per plant. Positive significant genotypic correlation existed between days to $50 \%$ flowering and latex yield per plant $(0.53 *)$ meaning thereby that long duration genotypes yield more latex. Significant positive genotypic correlation was also found between peduncle length and plant height $(0.49 *)$, peduncle length and morphine content $\left(0.46^{*}\right)$, number of effective capsule per plant and seed oil content $(0.53 *)$, diameter of main capsule and stem diameter $\left(0.61^{* *}\right)$, diameter of main capsule and morphine content $\left(0.47^{*}\right)$ and between harvest index for seed yield and seed oil content $(0.92 * *)$.

Persual of data revealed that there exists significant negative correlation at genetic level between peduncle length and days to $50 \%$ flowering $(-0.47 *)$, between number of effective capsule and peduncle length ($\left.0.90^{* *}\right)$ and number of effective capsule and plant height $\left(-0.66^{* *}\right)$. The harvest index for seed yield exhibited significant negative association at genotypic level with stem diameter $\left(-0.61^{* *}\right)$, seed yield per plant ($\left.0.45^{*}\right)$ and husk yield per plant $\left(-0.56^{* *}\right)$ indicating little importance of these trait. Harvest index for latex yield, seed oil content and morphine content exhibited nonsignificant association with all other characters studied.

Similar trends of results were reported by Khanna and Singh (1975), Saini (1982), Sethi et al., (1990), Lal et al., (1996), Singh et al., (2000), Shukla et al., (2003), Jain et al., (2005), Jain et al., (2006), and Singh and Singh (2008) who reported positive correlation of most of the traits with seed yield per plant.

It can be concluded from the above findings that main yield contributing traits are days to 50 percent flowering, peduncle length, number of effective capsule per plant, diameter of main capsule, stem diameter, husk yield per plant, latex yield per plant due 
to their direct high positive association with seed yield. It indicated the possibilities of simultaneous improvement of these traits by selection, which in turn will improve the seed yield, since they are positively correlated with the seed yield.

The trait harvest index for seed yield had negative and significant correlation with seed yield per plant thereby indicating selection for early maturity would give draught tolerant and drought avoiding genotypes affecting the seed yield positively in opium poppy.

Path coefficient analysis for seed yield per plant

The direct and indirect effects of ten dependent characters on seed yield per plant as independent character was obtained in path coefficient analysis at genotypic level (Table $3)$.

It revealed from the path analysis for seed yield per plant that number of effective capsules per plant (73.04) exhibited maximum positive direct effect on seed yield followed by stem diameter (59.55), peduncle length (29.35), plant height (25.91) and morphine content (21.33). Number of effective capsule per plant also exhibited reasonable higher indirect effect on seed yield via seed oil content (38.98), days to 50 per cent flowering (26.06), husk yield per plant (26.03), diameter of main capsule (23.11), morphine content (15.08) and number of leaves per plant (4.90).

Table.1 List of opium poppy genotypes used for present investigation

\begin{tabular}{cll}
\hline S. NO. & Genotypes & Source \\
\hline 1. & UOP 20 & MPUAT Udaipur \\
2. & UOP 30 & MPUAT Udaipur \\
3. & UOP 35 & MPUAT Udaipur \\
4. & UOP 44 & MPUAT Udaipur \\
5. & UOP 50 & MPUAT Udaipur \\
6. & UOP 53 & MPUAT Udaipur \\
7. & UOP 60 & MPUAT Udaipur \\
8. & UOP 68 & MPUAT Udaipur \\
9. & UOP 69 & MPUAT Udaipur \\
10. & UOP 78 & MPUAT Udaipur \\
11. & UOP 79 & MPUAT Udaipur \\
12. & UOP 80 & MPUAT Udaipur \\
13. & MPO 4 & NDUAT Faizabad \\
14. & MPO 99 & COHF Mandsaur \\
15. & UOP 390 & MPUAT Udaipur \\
16. & UOP 590 & MPUAT Udaipur \\
17. & UOP 1185 & MPUAT Udaipur \\
18. & IC 42 & IARI New Delhi \\
19. & CHETAK APHIM & MPUAT Udaipur \\
20. & MOP 540 & COHF Mandsaur \\
\hline
\end{tabular}


Table.2 Genotypic (rg) and phenotypic (rp) correlation coefficients between different characters in opium poppy

\begin{tabular}{|c|c|c|c|c|c|c|c|c|c|c|c|c|c|c|}
\hline Character & DF & $\begin{array}{l}\text { PL } \\
(\mathbf{c m})\end{array}$ & $\begin{array}{l}\text { PL } \\
(\mathrm{cm})\end{array}$ & LPP & ECP & $\begin{array}{l}\text { CD } \\
(\mathrm{mm})\end{array}$ & $\begin{array}{l}\text { SD } \\
(\mathbf{m m})\end{array}$ & $\begin{array}{l}\text { SY } \\
(g)\end{array}$ & $\begin{array}{l}\text { HY } \\
\text { (g) }\end{array}$ & $\begin{array}{l}\text { LY } \\
(g)\end{array}$ & $\begin{array}{l}\text { HISY } \\
(\%)\end{array}$ & $\begin{array}{l}\text { HILY } \\
(\%)\end{array}$ & $\begin{array}{l}\text { SOC } \\
(\%)\end{array}$ & $\begin{array}{l}\text { MC } \\
(\%)\end{array}$ \\
\hline DF & & $-0.47 *$ & 0.06 & 0.02 & 0.36 & 0.22 & 0.06 & -0.08 & -0.13 & $0.53 *$ & 0.04 & -0.13 & 0.05 & 0.35 \\
\hline PL (cm) & -0.25 & & $0.49 *$ & -0.13 & $\overline{-}-90 * *$ & -0.09 & -0.15 & -0.35 & -0.25 & -0.40 & 0.11 & -0.28 & -0.29 & $0.46^{*}$ \\
\hline PH (cm) & 0.08 & 0.23 & & -0.12 & $\begin{array}{l}- \\
0.66^{* *}\end{array}$ & -0.01 & 0.03 & 0.11 & -0.01 & 0.31 & 0.16 & 0.16 & -0.36 & 0.25 \\
\hline LPP & -0.02 & -0.05 & -0.16 & & 0.07 & -0.09 & 0.01 & -0.06 & -0.15 & 0.12 & 0.06 & -0.36 & $-0.52 *$ & 0.17 \\
\hline ECP & 0.17 & -0.16 & -0.24 & 0.08 & & 0.32 & -0.01 & 0.21 & 0.36 & -0.11 & 0.19 & $-0.52 *$ & $0.53 *$ & 0.21 \\
\hline CD (mm) & 0.16 & -0.10 & 0.00 & -0.06 & 0.16 & & $0.61 * *$ & $0.60 * *$ & $0.59 * *$ & 0.16 & -0.33 & 0.24 & -0.00 & $0.47 *$ \\
\hline SD (mm) & -0.02 & 0.12 & -0.02 & -0.02 & -0.05 & 0.27 & & 0.28 & $0.57 * *$ & 0.09 & $-0.61 * *$ & 0.39 & -0.32 & -0.40 \\
\hline SY (g) & 0.02 & -0.12 & 0.05 & -0.10 & 0.13 & 0.29 & 0.25 & & 1.09 & $0.60 * *$ & $-0.45 *$ & 0.44 & 0.14 & 0.23 \\
\hline HY (g) & -0.06 & -0.09 & -0.06 & -0.09 & 0.17 & 0.32 & 0.27 & $0.77 * *$ & & 0.32 & $-0.56 * *$ & 0.26 & -0.01 & 0.11 \\
\hline LY (g) & 0.26 & -0.23 & 0.19 & 0.17 & 0.04 & 0.21 & -0.10 & 0.37 & 0.25 & & 0.30 & 0.39 & 0.43 & 0.12 \\
\hline HISY (\%) & -0.01 & 0.06 & 0.02 & 0.02 & -0.05 & -0.22 & -0.33 & -0.20 & -0.35 & 0.02 & & -0.35 & $0.92 * *$ & -0.43 \\
\hline HILY (\%) & -0.19 & 0.00 & 0.09 & -0.25 & -0.34 & 0.17 & 0.21 & 0.10 & 0.11 & 0.18 & -0.16 & & 0.14 & -0.05 \\
\hline $\operatorname{SOC}(\%)$ & 0.14 & -0.12 & -0.19 & -0.20 & 0.09 & 0.05 & -0.32 & 0.02 & 0.00 & 0.15 & 0.31 & 0.01 & & -0.31 \\
\hline $\mathrm{MC}(\%)$ & 0.05 & 0.14 & 0.22 & 0.09 & 0.16 & 0.25 & -0.03 & 0.07 & 0.08 & 0.03 & -0.10 & -0.13 & -0.17 & \\
\hline
\end{tabular}

Table.3 Direct (diagonal) and indirect effects of different characters towards seed yield per plant in opium poppy

\begin{tabular}{|c|c|c|c|c|c|c|c|c|c|c|c|}
\hline Character & DF & PL (cm) & PH (cm) & LPP & ECP & CD (mm) & $\mathrm{SD}(\mathrm{mm})$ & HY (g) & $\operatorname{SOC}(\%)$ & MC (\%) & $\mathbf{r}$ \\
\hline$\overline{\mathrm{DF}}$ & -19.06 & -13.77 & 1.58 & -0.21 & 26.06 & -9.74 & 3.48 & 4.22 & -0.02 & 7.40 & -0.08 \\
\hline PL (cm) & 8.95 & 29.35 & 12.82 & 1.43 & -65.82 & 4.00 & -8.99 & 7.94 & 0.14 & 9.83 & -0.35 \\
\hline $\mathrm{PH}(\mathrm{cm})$ & -1.16 & 14.52 & 25.91 & 1.34 & -48.18 & 0.35 & 1.59 & 0.18 & 0.17 & 5.39 & 0.11 \\
\hline LPP & -0.38 & -3.91 & -3.23 & -10.77 & 4.90 & 3.94 & 0.80 & 4.70 & 0.25 & 3.63 & -0.06 \\
\hline $\mathrm{ECP}$ & -6.80 & -26.44 & -17.09 & -0.72 & 73.04 & -13.83 & -0.59 & -11.50 & -0.25 & 4.40 & 0.21 \\
\hline $\mathrm{CD}(\mathrm{mm})$ & -4.25 & -2.68 & -0.21 & 0.97 & 23.11 & -43.73 & 36.35 & -18.91 & 0.00 & 9.94 & $0.60 * *$ \\
\hline $\mathrm{SD}(\mathrm{mm})$ & -1.11 & -4.43 & 0.69 & -0.14 & -0.72 & -26.70 & 59.55 & -18.39 & 0.15 & -8.63 & 0.28 \\
\hline $\mathrm{HY}(\mathrm{g})$ & 2.49 & -7.22 & -0.14 & 1.57 & 26.03 & -25.63 & 33.94 & -32.27 & 0.01 & 2.30 & 1.09 \\
\hline $\operatorname{SOC}(\%)$ & -0.94 & -8.57 & -9.33 & 5.61 & 38.98 & 0.22 & -19.12 & 0.39 & -0.47 & -6.64 & 0.14 \\
\hline $\mathrm{MC}(\%)$ & -6.62 & 13.52 & 6.54 & -1.83 & 15.08 & -20.37 & -24.08 & -3.49 & 0.15 & 21.33 & 0.23 \\
\hline
\end{tabular}

** Significant at $1 \%$ level of significance 
Int.J.Curr.Microbiol.App.Sci (2017) 6(8): 1116-1123

Table.4 Direct (diagonal) and indirect effects of different characters towards latex yield per plant in opium poppy

\begin{tabular}{|c|c|c|c|c|c|c|c|c|c|c|c|}
\hline Character & DF & PL (cm) & PH (cm) & LPP & ECP & $\mathrm{CD}(\mathrm{mm})$ & SD $(\mathbf{m m})$ & HY (g) & $\begin{array}{l}\text { SOC } \\
(\%)\end{array}$ & $\operatorname{MC}(\%)$ & $\mathbf{r}$ \\
\hline$\overline{\mathrm{DF}}$ & -19.05 & -15.20 & 1.69 & -0.21 & 27.78 & 10.52 & 3.74 & 4.52 & 0.03 & 7.75 & $0.53 *$ \\
\hline PL (cm) & 8.94 & 32.39 & 13.75 & 1.41 & -70.18 & 4.32 & -9.66 & 8.50 & -0.18 & 10.29 & -0.40 \\
\hline PH (cm) & -1.16 & 16.03 & 27.80 & 1.32 & -51.37 & 0.38 & 1.71 & 0.19 & -0.22 & 5.64 & 0.31 \\
\hline LPP & -0.38 & -4.31 & -3.46 & -10.59 & 5.23 & 4.26 & 0.86 & 5.03 & -0.31 & 3.80 & 0.12 \\
\hline ECP & -6.80 & -29.19 & -18.34 & -0.71 & 77.88 & -14.95 & -0.63 & -12.31 & 0.32 & 4.61 & -0.11 \\
\hline $\mathrm{CD}(\mathrm{mm})$ & -4.24 & -2.96 & -0.22 & 0.96 & 24.64 & -47.25 & 39.09 & -20.25 & -0.00 & 10.40 & 0.16 \\
\hline SD (mm) & -1.11 & -4.89 & 0.74 & -0.14 & -0.77 & -28.85 & 64.03 & -19.69 & -0.19 & -9.03 & 0.09 \\
\hline HY (g) & 2.49 & -7.97 & -0.15 & 1.54 & 27.76 & -27.69 & 36.49 & -34.55 & -0.01 & 2.41 & 0.32 \\
\hline SOC (\%) & -0.94 & -9.46 & -10.00 & 5.52 & 41.56 & 0.23 & -20.56 & 0.41 & 0.60 & -6.95 & 0.43 \\
\hline $\mathrm{MC}(\%)$ & -6.61 & 14.93 & 7.02 & -1.80 & 16.08 & -22.01 & -25.89 & -3.73 & -0.19 & 22.34 & 0.12 \\
\hline
\end{tabular}

*Significant at 5\% level of significance 
Diameter of main capsules (-43.73), husk yield per plant (-32.23), days to 50 per cent flowering (-19.06) and number of leaves per plant also directly contributed to seed yield with negative estimates. It is concluded from above results that seed yield per plant can be improved practicing selection for number of effective capsules per plant, stem diameter, peduncle length and plant height as they contributed directly to the seed yield as revealed from path analysis.

These findings are in consonance to the results obtained by Shukla et al., (2003) and Ozturk and Gunlu (2008) who have also reported high positive direct effect of plant height, capsule size and stem diameter on seed yield per plant. Mirjana et al., (2012) also reported the high positive direct effect of number of capsules per plant and diameter of main capsule over seed yield per plant. The component of residual effects of path analysis was -29.70. The low residual effect indicated that characters for path analysis were adequate and appropriate.

\section{Path coefficient analysis for latex yield per plant}

It is revealed from the path analysis for latex yield per plant that number of effective capsules per plant (77.88) exhibited maximum positive direct effect on seed yield followed by stem diameter, peduncle length, plant height and morphine content (Table 4). Higher positive indirect effect of number of effective capsule per plant on latex yield exhibited via seed oil content (41.56), days to 50 per cent flowering (27.78), husk yield per plant (27.76), diameter of main capsule (24.64), morphine content (116.08) and number of leaves per plant (5.23). It is concluded from above results that latex yield per plant can be improved practicing selection for days to 50 per cent flowering as indicated by path analysis.
These findings are in consonance to the results obtained by Shukla et al., (2003) had also reported high positive direct effect of plant height, capsule size, and stem diameter on seed yield per plant. Singh and Singh (2008) also reported the high positive direct effect of husk yield per plant, and seed yield per plant over latex yield per plant. The component of residual effects of path analysis was -33.96. The low residual effect indicated that characters for path analysis were adequate and appropriate.

\section{References}

AOAC. 1965. "Official methods for oil analysis for association of Official Agricultural Chemists" $10^{\text {th }}$ Ed. Washington, D.C.

Al-Jibouri, H.A., Millar, P.A., Robinson, H.F. 1958. Genotype and environmental origin. Agron. J., 50: 633-637.

Anonymous. 2011. Rajasthan agricultural statistics at a glance for year 2010-11. Commission rate of agriculture Rajasthan, Jaipur (Statistics Cell) pp-111.

Dewey, D.R., Lu, K.H. 1959. A correlation and path coefficient analysis of components of wheat grass seed production. Agron. J., 51: 515-518.

Duke, J.A. 1989. CRC Handbook of Nuts. CRC Press, Boca Ratan, FL, pp 240-243.

Fisher, R.A. 1954. Statistical methods for research workers. 12 $2^{\text {th }}$ Edn., Biol. Monograph and Manuals, 5: 130-131.

Harvey, J. 1988. Alternative crops on starcross experimental plots. Silsoe Research Institute, UK.

Jain, D.K., Jain, S.K., Bordia, P.C., Joshi, A. 2005. Study of genetic variability and correlation in germplasm of opium poppy (Papaver somniferum L.). Res. Crops, 6: 112-115.

Jain, S.K., Dodiya, N.S., Joshi, A. 2006. Genetic variability and character association in opium poppy (Papaver somniferum L.). J. Med. Aromatic Plant Sci., 28: 190-193.

Khanna, K.R., Singh, U.P., 1975. Correlation studies in Papaver somniferum L. and their bearing on yield improvement. Planta 
Medica, 28: 92-96.

Kumar, B., Mali, H., Gupta, E. 2014. Genetic variability, character association, and path analysis for economic traits in menthofuran rich half-sib seed progeny of Mentha piperita L. BioMed. Res. International.

Lal, R.K., Sharma, J.R., Misra, H.O., Sharma, S. 1996. Divergence analysis and characters association in opium poppy (Papaver somniferum L.). J. Medicinal and Aromatic Plant Sci., 18: 502-504.

Mirjana, J., Sonja, I., Gjoshe, S., Jelena, A., Ljupcho, J., Danem, B. 2012. Interrelationship between seed and capsule yield and yield contributing characters in opium poppy (Papaver somniferum L.). Agrarni Nauki, 4: 13-17.

Namrata, Sharma, H., Ranwah, B.R., Bisen, P., 2016. Variability Assessment and Path Coefficient Analysis in Groundnut (Arachis hypogaea L.) Genotypes in Sub- Humid Southern Plains of Rajasthan. Trends in Biosci., 911): 642-646.

Ozturk, O., Gunlu, H. 2008. Determining relationships amongst morphine, capsule and oil yield using path coefficient analysis in opium poppy (Papaver somniferum L.). Asian J. Chemistry. 20: 2979-2988.

Patra, N.K., Ram, R.S., Chauhan, S.P., Singh, A.K. 1992. Quantitative studies on the mating system of Opium poppy (Papaver somniferum L.). Appl. Genetics, 84: 299302.

Pride, R.P., Stern, E.S. 1954. A specific method for the determination of morphine. Indian $J$. Pharmacy and Pharmacol., 6: 590-606.

Singh, S.P., Shukla, S., Yadav, H.K. 2004. Genetic studies and their implication to breed desired plant type in opium poppy
(Papaver somniferum L.). Genetika, 36(1): 69-81.

Saini, H.C., Kaicker, U.S. 1982. Model plant architecture through association and pathcoefficient analysis in opium poppy. Indian J. Agri. Sci., 52: 744-747.

Sethi, K.L., Sapara, R., Gupta, R., Dhindsa, K.S., Sangwan, N.K. 1990. Performance of poppy cultivars in relation to seed oil and latex yield under different environments. $J$. Sci. Food \& Agri., 52: 309-313.

Shukla, S., Yadav, H.K., Singh, S.P. 2003. Path coefficient analysis for seed yield in opium poppy (Papaver somniferum L.). Proceedings of the National Academy of Sciences India, Section B, Biol. Sci., 73: 8388.

Singh, O.P, Singh, T.P., Yadav, A.L., Yadav, P.N. 2000. Genetic variability, genotypic and phenotypic correlation in germplasm of opium poppy (Papaver somniferum L.). Adv. Plant Sci., 13: 69-73.

Singh, S.K., Singh, O.P. 2008. Character association among some morphological traits and path coefficient analysis in opium poppy. Adv. Plant Sci., 21: 147-150.

Singh, S.P., Khanra, K.R., Dixit, B.S., Srivastava, S.N. 1990. Fatty acid composition of opium poppy (Popover somniferum L.) seed oil. Ind. J. Anric. Sci., 60: 358-359.

Tiwari, R.K., Singh, S.P., Dubey, T. 2000. Correlations in opium poppy and their implication in selection. J. Medicinal and Aromatic Plant Sci., 22: 264-267.

Yadav, H.K., Shukla, S., Singh, S.P. 2008. Discriminant function analysis for opium and seed yield in opium poppy (Papaver somniferum L.). Genetika, 40(2): 109-120.

\section{How to cite this article:}

Gurudatt Solanki, N.S. Dodiya, Ram Kunwar, Prashant Bisen, Ramesh Kumar, Jagjeet Singh and Sandhya. 2017. Character Association and Path Coefficient Analysis for Seed Yield and Latex Yield in Opium Poppy (Papaver somniferum L.). Int.J.Curr.Microbiol.App.Sci. 6(8): 1116-1123. doi: https://doi.org/10.20546/ijcmas.2017.608.138 